\title{
Social Networking Services in Service of Democracy - Chosen Case Studies
}

\section{Małgorzata Laskowska, University of Cardinal Stefan Wyszynski in Warsaw, Poland}

\begin{abstract}
The author undertook to define the role of the social networking services and their meaning for democracy, especially in those countries lacking democracy. At the beginning of this analysis the following questions were formulated: To what extent are the social networking media able to change and/or create democracy? What possibilities for the citizens do they offer? What characterizes a community created by the social networking services? How permanent and valuable is it in the context of the quest for democracy and its strengthening? Answering these questions shall allow for making conclusions precious particularly for those who would like to make use of social networking services in order to promote democratic values.
\end{abstract}

Keywords: new media, social media, democracy, freedom 


\section{Introduction}

The beginnings of democracy date back to 6th century B.C. and it first appeared in Greece. The term "democracy" consists of two words: demos (people) and "kratein" (to rule), referring to "rule of the people". There are two ways of thinking about this notion. First of them applies to defining a political system of a country in which the supreme power is vested in the people and exercised by all of them, while the other refers to the way in which the democratic system functions, based on the rules of freedom, equality, justice and development possibilities (Król, 1989: 5; Zwoliński, 2010). In the age of universal access to the information - due to the Internet - changes in many areas have been noticed, concerning society, culture, and politics as well. Among others, people start to ask questions about the understanding of democracy in the era of the new media.

Therefore, the aim of this article is to try answering the questions: What is the value of the social networking services in the context of media and political systems? How do these services influence the politics and media? To what extent are the social networking services able to change and/or create democracy? What possibilities for the citizens do they offer? What is their role in the political communication? How is democracy understood in the age of the Internet? What are the elements characterizing a community created and maintained by social networking services? In order to answer these questions, first the focus was put on defining the notion of social networking services, which is clear and unequivocal. Next, after analyzing the reference literature, the concept of network community was described, aiming at determining, whether one can really say about the community of the network and the community-forming role of the social networking services. Finally, the way of understanding democracy in the Internet was presented, followed by a reflection on the notion of freedom in the social network. Such an arrangement of the article chapters shall, according to the author, allow for proper evaluation of the social networking services significance in the context of creating and strengthening the democratic system, particularly in the countries struggling with communism or socialism, as well as those where freedom of speech and expression is limited in any way.

\section{Social Networking Services - Definition and Characteristics}

Although the number of researches and case studies on social media increases, there is still no clear and unambiguous definition of them. It is easier to enumerate the Internet tools which 
hiding under this name than to explain the notion itself. The term "social media" includes blogs and microblogs, YouTube, social networking services and Wiki (Evans, 2011: 21-25). As G. Miller, points out, these elements are a combination of different the web 2.0 tools and as such they ,allow for publishing visual materials, films, creating groups, inviting other users to different events, publishing ads and integrating other applications" (Miller, 2012: 43). A particularly good example of that are Facebook and Twitter, which shall be discussed further on. The social networking services are described by means of different terms, such as social network, e-network and social network sites (SNS). These Internet services are used mainly for communicating with other users and sharing information, by the use of instruments such as chat rooms, forums, instant messaging and private messages. In the context of social networking services W. Gogołek says about "personalization of the media": "The 19th century was an era of newspapers; the 20th - of radio and television, while the 21 st century becomes - due to the information technologies - a period of media personalization, during which information is delivered the moment the demand for it is expressed by an individual, increasingly independently from the geographic place of the information receipt" (Gogolek, 2010: 173).

Without doubts, these words leave a considerable mark on the foundation of the 21 st century democracy. The notion of „media personalization” refers very strongly to the social media, since they are the instrument used for expressing individual and personal feelings, ideas, dreams; visions etc. by use of these media can the Internet user can participate in public discussions quickly and easily. Numerous examples confirm that due to the social networking services a statement of an average citizen may be noticed. Hence everyone can (if he only wants) come into existence in the awareness of the society. It also means individual purpose of the media, i.e. its every user is free to choose the information interesting to him and thus create a personalized infoSphere according to his individual preferences. On the one hand, this personalization of the media instills optimism, but on the other - in the context of democracy - evokes fear for its future and its citizens in particular.

Personalization of the new media may also be a consciously applied manipulative technique. In this sense, it is understood as misleading the receiver towards a conviction that the offer of the new media is fitted to and prepared especially for him. The aim of such operation is making the receiver feel exceptional and spend as much time as possible in the world of such 
media, benefiting as much as possible from their information and communication possibilities, which - in excess - is obviously disadvantageous to the receiver and does not verve well his development. Nevertheless, the commercial profits are here enormous.

However, it is worth pointing out that the personalization of the media might also be understood as a process of cumulating data, regarding the way in which one uses the web, the result being Internet information (appearing particularly in the search engines) adequate to the user's interests, which are created e.g. on the basis of his search history. As such, this is information on the user himself (his interests, views, expectations), as well as about his methods of using the Internet, which is not insignificant in the context of the national security, since a profile of a user of any nationality can be created very easily.

\section{Social Networking Services - Space for a Community}

Apart from playing an important role in the areas of information, communication, entertainment, education and upbringing, the social networking services also participate in the process of creating communities and societies. The term "community" denotes close relationships among people, which result from "the existence of certain commonly accepted focal point, e.g. generally accepted religion"(Mikołajewska, 1989: 11). According to F. Toennies, a community is basically characterized by blood, brother ship and neighborhood relationships, and people joining together according to their personality types - getting thus involved into emotional relationships - a community is about persons, as opposed to an organization, dominated by factual and rational connections (Sztompka, 2002). "Society”, on the other hand, is a large and clearly distinguished form of living in a group, whose members are guided spontaneously by natural laws, creating thus cultural values, behavioral patterns and forms of activity. B. Szacka writes, that the basic circumstances for a community to develop is its existence for generations and, subsequently, having common norms and values, which make up the culture (Szacka, 2003: 184), while social group denotes "a set of people having a common characteristic or just accidentally existing in the same place or undertaking the same activity in the same time, or even - just a number of people" (Kozłowska, 2006: 188-189).

Since the beginnings of the Internet and the mediated communication, the definition of the web community or virtual community has been discussed. First of all, some questions appear: 
To what extent is it possible to create a community on the basis of social networking services? And to what extent is it a community? In this context, particularly important is the question concerning the integrative potential - to what extent the Internet creates circumstances allowing for creating a permanent and enduring community.

According to M. Graszewicz and D. Lewiński one should cautiously approach the idea that the Internet plays a role in creating the society. "One can hear very optimistic voices saying that the interactive forms of Internet communication create a new type of social relationship. But it is easy to notice that most of these purely the web communication processes is separated from their natural social spheres. When we communicate in a standard way (beyond the Internet), the communication process involves the symbolic potentials of the actors, like the field position regulating the communicative resources, as well as systems of responsibility and correlations. In the Internet, which allows for anonymity, communication processes are somehow deprived of the responsibility systems. Everyone can tell everyone whatever and how he wants. The communication may be broken without any social consequences or sanctions. We may avoid communicating in situations when during standard social interactions it would be impossible not to communicate. The Internet is a place of social irresponsibility. Therefore, the ideas of Internet communication as co-creating society should be treated suspiciously. Only when the Internet relationships lead to meeting beyond Internet, can we say about socializing" (Graszewicz and Lewinski, 2011: 22).

The opinion above is supported by many researchers (Poleszczuk, 2010: 34). Their cautiousness towards the integrating function of the Internet influences as well the judgment concerning the role of the web in the area of democracy. Since we cannot say about an Internet community, it is difficult to prove the web to be a potential danger for the existence of real national community. According to the idea described above, the real community is more permanent, while the virtual - more ephemeral and global (beyond borders, one tradition and history), and as such extremely difficult to be described purely in the terms characterizing a real society or community.

However, there are researchers convinced about the existence of the web society or virtual society and they defend their stance. In order to describe the societies created in the web, M. Klimowicz suggests using one of the following terms: "virtual communities", "web 
communities" and "Internet communities" (Klimowicz, 2008: 83). With regard to the social media they seem to be adequate and precise enough, because the phenomenon described thus is understood as a society created on the basis of global relationships in the virtual space (Stalder, 2006: 10-13).

In the context of democracy it is also worth taking into account the dangers connected with web communities. They result from comparing the Internet to „the Wild West, i.e. the general American pattern of conquering and managing the space. The no man's land located 'between' areas having owners is in many places desolated and becomes ruined. So the computer and Internet user is at the same time a navigator and an explorer of such places" (Sierocki and Sokołowski, 2011: 27; Olcon-Kubicka, 2008). This situation results in different dangers, particularly for the internal security of the countries, but also for the national culture and tradition.

However, there are advantages as well. The Internet (especially social networking services) might be a good instrument allowing for realizing various projects (also the international ones), organizing initiatives, which are righteous but not necessarily supported by e.g. local government. In the context of democratization of the web or participation of the social networking services in supporting democracy, one should ask the following questions: To what extent is this web-based civic participation authentic? Do the people using the web to popularize freedom understand and appreciate? How do their activities correspond with the basic principles of democracy, i.e. individual liberty, equality before the law and protection of ownership? Further on the author shall try to answer these questions.

\section{Democracy in the Internet}

Democracy is understood as a political system, in which basic human laws are respected and circumstances necessary for their implementation are provided (Piwowarski, 1993). In order to grasp its essence better, it is worth referring to the history.

In the first democratic territory ever, the „demos" meant the Athenians. Every citizen of Athens was a free man having a right to vote. In order to limit the number of the eligible voters, in 451 B.C. it was decided that an Athenian citizen is only a person born to Athenian mother and father both. The citizens could express their will through voting on all kinds of 
issues. The law was written down and kept in archives or carved in stone. Ignorance of the law did not excuse breaking it. The Greek democracy was of the so-called direct type. The name itself derives from two Greek words, demos (people) and creatos (to rule), which means direct rule of the people, direct participation of the citizens in the making public decisions, e.g. through referendum or plebiscite (indirect democracy allows for making public decisions or choices also against the will of the voters). Significant elements of the "first" democratic system were discussions of two types. First of them was a kind of speech directed to the people, while the other - a political discussion led in front of the tribunal and concerning a particular act. Particularly strong element of the Athenian political system was the model of local democracy. Its secret was the civic consciousness of the absolute necessity of participating in public life as an expression of concern for the common good (Vidal-Naquet and Brisson, 2007: 13-47).

Due to the Internet one can talk about the direct democracy, hence the web space has been compared to the ancient agora by M. Hardt and A. Negrie: "Appearance of the multitude, its transformations in the form of the web and the possibility of making decisions in the name of everyone resulted in the fact that for the first time in the history of mankind democracy became possible. (...) Democracy becomes possible when the multitude is finally able to rule itself" (Hardt and Negri, 2005: 340)

The modern technology forces also changes in the fields more or less related to democracy, such as the economy and forms of exercising political power. Analogue instruments - used by science, sports, health care, politics, transport, and media - are being replaced with the digital and web-based ones. The Internet became the main foundation for any activities, particularly those connected with transferring the knowledge, information and with communicating. According to M. Megier the new forms of communication also have influence on the economy, creating thus the so-called "new economy": "The digital technologies, the Internet, the computers and global information networks lead to the increased production effectiveness, make the goods and services exchange easier and allow for cooperation and activities coordination in all spheres of the economy, within its sectors and among them as well" (Megier, 2011: 30; see: Kung, 2008; Albaran and Chan-Olmsted and Wirth (ed.), 2006; Doyle, 2013; Welch, 2012). 
Above others, the new media affect very strongly their own sector, changing thus the media system (Jedrzejewski, 2009: 143). It was commented very aptly by B. Ociepka, who says that: "The large-scale use of the new technologies influences changes in media system and the receivers' behavior. But the legal systems concerning the media are not able to keep pace with these changes, which results in delayed introduction of regulations concerning functioning of the new media. The new technologies also force changes concerning the media ownership. The best example is the satellite and cable TV broadcasting, which resulted in elimination of the barrier in the form of lack of free frequencies for all those who wanted to broadcast radio and TV programs" (Ociepka, 1999: 150). The new media also become the main source of the media convergence, which is a characteristic of the modern media market and a result of the diffusion of among others the information, telecommunication and media markets (Adamski, 2012: 150-195).

The new media also shape the politics (the way of exercising the power), but also they determine the participation of the citizens in making national key decisions or serve the defense of civic rights. Therefore, the idea of democracy in the Internet can be analyzed in three ways.

First of all, democracy in the Internet can be understood literally, as an electronic democracy. This is another issue difficult to be defined, because of the high dynamics of the Internet and broadening of "the field of activity run by the institutions and subjects existing before" (Gulda, 2005: 116). However, one could conclude, that this term determines the influence of "the ICT on the political processes and the phenomenon of connecting the computer technology with the political processes" (Nowina Konopka, 2006: 83). Then it would mean a new form of political communication - using new technologies to exercise power, i.e. "using the electronic webs for creating a more direct form of democracy" (Porębski, 2001: 47). Electronic democracy understood in this way includes among others: online debates, eadministration, online voting.

In this context, the role of the electronic media was aptly described by J. Sobczak, according to whom (Sobczak, 2007: 336):

- above all, they function as ,agents and initiators of the communication between political system institutions and the citizens", 
- they evoke interest in social issues,

- they create or constitute the public opinion.

Confronted with technological development, democracy acquires thus a new character. Due to popularized Internet usage in the political communication, more and ore often we say about teledemocracy, technopolitics or electronic democracy, which assume new forms of transferring information or new voting procedures. According to M. Musiał-Karg - this is a kind of "sign of the times" (Musiał-Karg, 2009: 212; Nowak, 2011; Jakubowicz, 2010; Hofmokl, 2009).

The question of democracy in the Internet can also be approached and interpreted form other perspective - noting how powerfully does is the Internet influence the public opinion, and views of the society which shape democracy or determine the lack of it. Above all, the media described as the fourth estate fit into the protection of democratic system. Of course, this role is assigned primarily to the public media. However, it is quite different in practice. In the context of Polish public media, J. Jastrzębski notices that "There are growing fears of manipulation and misinformation, based on the awareness of the economic and political involvement of large media corporations. General suspicion of the media which define themselves as independent is intensified by the media commercialization, concentration and non-transparent ownership, as well as by the links with the big money. It is generally sensed that the media represent to a lesser extent the cognitive interest of the common man as well as needs of various social groups and society treated as a community united by group goals and aspirations. Alienation of the media in the developed countries and mature democracies is expressed by the visible decline of trust: people are inclined to believe in state administration rather than in the media. This means a deep crisis of the democratic media doctrine, assuming the media to be an institution that watches and controls the doings of the authorities, as well as organizes the public opinion. Such functions of the media as informing and commenting are in decay, giving up the place to pervasive entertainment" (Jastrzębski, 2011: 34; Magoska, 2009: 67-73).

Therefore, public media leave much to be desired. Their weakening influence on the community might be one of the reasons for the growing popularity of the social media, social 
networking services in particular. Here at least the citizen is able to express his view, having at the same time access to the information not necessarily appearing e.g. in the TV news.

The third approach to the idea of democracy in the Internet is related to the use of the webbased instruments for the purposes of social activity in aid of fight for democracy, such as above all - the social networking services used by common citizens who do not exercise authority but are interested in the political and social situation of the nation.

\section{The Definition and Understanding of the Freedom in the Social Networking Services}

The attributes of democracy are freedom and sovereignty. It is worth discussing these notions in the context of the social networking services. There are numerous definitions of freedom. For Descartes it was the source of human dignity, and, as such, the basis of „self-respect”. In Hegel's time a distinction of two types o freedom appeared: negative liberty ("freedom from something" - from external restraint, like war, hunger, fear etc.) and positive liberty ("freedom to do something"), where the stress is on the possibility of making a choice and one's right to something. But in case of both individual and collective freedom the truth appears as a task. And the first and basic step towards fulfilling it is receiving the truth, which - according to St. Thomas Aquinas - is rooted in the rational order (Maryniarczyk, 1997: $313)$.

Freedom approached in this way has a lot on common with the freedom related to a state. Therefore, the sovereignty of a nation is nothing else but independent and therefore unimpeded exercising of the authority within a state's territory. One can differentiate between the internal sovereignty (decisions and activities of the authorities and independent from internal relationships, organizations, institutions etc.) and external sovereignty (in dependence in the context of making decisions concerning a state behind its borders). In case of democracy, apart from the authorities the guarantor and the object of the sovereignty are also the people. Ma on decydujące znaczenie i możliwości w kreowaniu demokracji, a przede wszystkim w podtrzymywaniu jej w świadomości i organizacji politycznej i społecznej (Canovan, 2003: 7-70; Schmitt, 2000: 33-60; Maritain, 1993: 35-61).

Closely related to freedom are the human rights. In case of sovereign state a given nation's rights of its own identity, culture, language, history and territory are respected, while for an 
individual citizen these rights are defined by the constitution. Constitution of Poland of 27 April 1997 separates personal, political, as well as economic, cultural and social civic rights and freedoms.

The first group includes the right to live, inviolability and personal freedom, the right to a fair trial, the right to legal protection of personal life, the right of parents to raise children according to their own beliefs, the right to liberty and protection of the communications privacy, right to protection against the breach of domicile, freedom of movement within the state borders, freedom of conscience and religion, freedom of expression and communication.

The political rights and freedoms are composed of the following: the right to organize peaceful assemblies and participate in them, the freedom to associate, the freedom to associate in the trade unions, social and political organizations, the right to participate during the referendum, and the right to vote for a president, MPs, senators and the local governments authorities, the right to submit the claims, petitions and complaints.

The economic, social and cultural freedoms and rights include: the right to property, the right to inherit, freedom to chose the workplace, the right to work in safe and hygienic environment, the right to social benefits in case of incapacity for work resulting from illness, disability or old age, the right to health protection, the right to education, the protection of children's rights, the right to artistic freedom and the right to research (Konstytucja Rzeczypospolitej Polskiej, 1997; Skorowski, 1995; Garlicki, 2011; Garlicki, 2007; Zubik, 2011).

\section{Social Networking Services as the Instrument of Fight for Human Rights}

Dependently on the political system the citizens of various states live in, they use in different ways the possibilities of the internet for fighting of their rights, including the respect of fundamental democratic rules. In Poland the most popular channel for expressing one's opinion and emotions connected with current social and political events is the Facebook, which can be exemplified by the social and political moods related to the so-called Independence March (or to the idea of patriotism itself), decisions of the government (GMO Act) and the catastrophe in Smolensk. 
However, it is worth to stress the reactions of the citizens of non-democratic countries. The role of the social networking services in the process of fight for civic rights has been widely discussed, especially in 2010 in the time of the Arab Spring in Tunisia. This name encompasses numerous protests of people expressing thus their disapproval of the unemployment, rise of prices, corruption and nepotism. These protests changed later into a real revolution. Later, similar events took place also in Egypt, Algeria, Yemen, Jordan, Bahrain and Libya (here the protests resulted in the beginning of a civil war). And people were called to go take to the streets mostly through the social networking services. It was there where substantial debates went on for days and nights, organizational issues were discussed. This made the citizens feel strong and united (just like they felt in case of the protests against ACTA).

The social networking services also played an important role in Belarus after the elections which took place at the turn of 2010 and 2011, as well as in Russia on 2012. Young people, organizers of the "Movement for the Future", started to arrange on-line meeting of Belarus youngsters via Vkontakte, a counterpart of Facebook, popular in Russia, and also in Belarus and Ukraine. Due to this, about 200,000 people joined the Movement. They also used to meet in a city square every Wednesday, which was quickly noticed by the state authorities. During the fourth meeting, its participants started to be arrested. According to the Freedom House report only $27 \%$ of Belarus citizens have access to the Internet, which is not only very expensive, but also technically difficult to be used at home (Freedom House, 2012). Apart from that, the Belorussians cannot use all of the social networking services. After the 2010 elections, when the government fount out how important and influential are the social media in the context of the civic communication, access to the international web was denied (among others - to Facebook and Gmail) (Kacprzak, 2012).

M. Castells, who analyzes among others the social movements, discussing the on-line sociopolitical groups, pointed out that: "They do not mean to take the power over, either by revolution or a march through the state institutions. They rather aim at creating new practices among their members [...] In fact, approaching the subject from the political point of view, the influence of the social movement is the result of the ability of concentrating the significant resources on just few problems, skipping at the same time the others" (Stalder, 2006: 218). 
Therefore the success of social movements - in the web or beyond it - would be based on the capability of associating around a concrete problem, in order to fight in unison for some rights. For the state authorities such an unanimous and determined voice seems to be very dangerous and more difficult to subdue, not even to mention manipulating it.

The social networking services are increasingly described and ,the fifth estate" (Cooper, 2006; Ward, Wasserman, 2010: 282). The traditional media (TV, press) often are referred to as the ,estate” and even more often as ,the first estate”. Such positioning of the media is not meaningless, for the democratic system in particular. According to the classical thought of K. Popper "Democracy depends on screening the political authorities in a certain way - this is the basis of democracy. In a democratic system there must not be a single authority not subject to control. Nowadays, the television became an extremely powerful authority perhaps the most powerful one of all of them - almost appearing to replace the voice of God. And this process is going to continue if we go on allowing this authority for malpractices. In the democratic system, the television has been granted too much of power. None of the democracies shall survive if we do not stop this omnipotence (Popper, 1996: 50-51).

Contemporarily, these words refer mainly to the Internet, which "due to its capacity, speed and potential availability becomes a medium of great significance for the development of the direct forms of democracy and transnational levels of the public" (Ociepka, 1999: 162). Therefore, it seems and urgent task to analyze the idea of democracy in the context of the Internet possibilities (particularly the web communities, integrating via the social networking services). P. Bielawski reminds that "the way in which the media function is not only a showcase of the democratic system, but also has a great influence on its content" (Bielawski, 2010: 24). According to W. Pisarek, when properly located within the democratic society, the media - also the new media - allow us for comprehending the scheme of authorities. He also claims that the exercising of power should follow the scheme: a problem - decision - action effects - evaluation done by the media (Pisarek, 2007: 176). At present, however, such a scheme is rather rare. The media try to influence the receiver already on the decision-making level, usurping thus the right to serve as the "first power" (Jastrzębski, 2007: 29). 


\section{Conclusions}

The analysis of the social networking services value in the context of democracy showed that these services can have real influence on the political moods, and in consequence also on the particular decisions and actions. The social communication instruments guard the idea of democracy and social durability, among others by facilitating access for the citizens and creating for them proper conditions for expressing their own opinions. But the mature and real democracy assumes the information to be honest, full and checked, i.e. meeting the highest standards of the journalistic. This is why the endless debate concerning the role of the media in democracy is so essential, aiming at exposing the activities which intensify the imperfectness of the media system. In order to start a public discussion, the citizens quickly started to use the social networking services. In democratic Poland, in the social media many issues are discussed - like the national security, Poland's sovereignty, especially in the context of the Smolensk catastrophe. Also, people chat about issues connected with view of the life or religion (role and place of the church within the society, conceived life, partnerships). In the time of national anniversaries, the social media are full of talks on problems belonging to the national axiology - the idea of patriotism or what it means to be a Pole. Such mottos are definitely a part of the debate on the future and shape of Polish democracy. However, the situation is completely different in the non-democratic countries, where the access to the Web and to the global social networking services plays a great role in the process of arranging meetings and fighting for civic rights. 


\section{References:}

Bielawski, P. (2010). Media publiczne - potencjalny fundament demokracji publicznej, in: Bielawski, P., Ostrowski, Andrzej, Media publiczne. System medialny w Polsce pytania i dezyderaty, Lena: Wrocław.

Canovan, M. (2008). Lud, transl. S. Szymański, SIC: Warsaw.

Cooper, S. (2006). Watching the watchdog: Bloggers as the fifth estate, Marquette Books: Washington.

Evans, L. (2011). Social Media Marketing. Strategies for engaging in Facebook, Twitter and other social media, transl. B. Sałbut, Wydawnictwo Helion: Gliwice.

Freedom House, http://www.freedomhouse.org/sites/default/files/FIW\%202012\%20Booklet_0.pdf

Garlicki, L. (ed.). (2007). Komentarz Rzeczypospolitej Polskiej z dnia 2 kwietnia 1997 roku. Komentarz, vol. I-V,Liber: Warsaw.

Garlicki, L. (2011). Polskie prawo konstytucyjne. Zarys wykładu, Liber: Warsaw.

Graszewicz M., Lewiński D. (2011). Wstęp do systemowej teorii Internetu, in: Nowe media we współczesnym społeczeństwie, ed. M. Jeziński, A. Seklecki, Ł. Wojtkowski, UMK: Toruń.

Gulda, P. (2005). Elektroniczna demokracja. Teoria i praktyka, wady i/lub zalety, in: U progu wielkiej zmiany. Media w kulturze XXI wieku, ed. M. Sokołowski, Kastalia: Olsztyn. Hofmokl, J. (2009). Internet jako nowe dobro wspólne, WAiP: Warsaw.

Jakubowicz, K. (2010). Unia Europejska a media. Między kulturą a gospodarką, WAiP: Warsaw.

Jastrzębski, J. (2011). Media i dziennikarstwo alternatywne, in: Nowe media we współczesnym społeczeństwie, ed. M. Jeziński, A. Seklecka, Ł. Wojtkowski, Adam Marszałek: Toruń.

Jastrzębski, J. (2007). Misja „,czwartej władzy” czy biznes? O potrójnej naturze mediów, in:

Media a demokracja, ed. L. Pokrzycka, W. Mich, UMCS: Lublin.

Kacprzak A. during a debate The purposes of freedom of the opinion. The record of this discussion was published in Res Publica Nowa of 4th February 2012, http://publica.pl/teksty/miedzy-wikileaks-a-egiptem-jak-wolne-sa-social-media/5

Konstytucja Rzeczypospolitej Polskiej (1997).

Kozłowska, A. (2006). Oddziaływanie mass mediów, Wydawnictwo: Szkoła Główna Handlowa w Warszawie: Warsaw. 
Król, M. (1989). Słownik demokracji, Res Publica: Kraków.

Magoska, M. (2009). O mediach, polityce i populizmie, in: Hofman, Iwona, Kępa-Figura, Danuta, Współczesne media. Status - aksjologia - funkcjonowanie, vol. 1, Wydawnictwo UMCS: Lublin.

Maritain, J. (1993). Pojęcie suwerenności”, in: Człowiek i państwo, ed. J. Maritain, transl. A. Grobler, Znak: Kraków.

Maryniarczyk, A. (1997). Wolność a prawda, in: Wolność we współczesnej kulturze, ed. Z. Zdybicka, J. Herbut, A. Maryniarczyk, Wydawnictwo KUL: Lublin.

Mikołajewska, B. (1989). Zjawisko wspólnoty (wybór tekstów), Wydawnictwo Uniwersytetu Warszawskiego: Warsaw.

Miller, G. (2012). Kryzys w mediach społecznościowych. Jak nim zarządzać? in: Zarządzanie w sytuacjach kryzysowych niepewności, ed. K. Kubiak, Wyższa Szkoła Promocji: Warsaw.

Musiał-Karg, M. (2009). Rola Internetu we współczesnych demokracjach, in: Współczesne media. Status - aksjologia - funkcjonowanie, vol. 2, ed. I. Hofman, I. Kępa-Figura, Wydawnictwo UMCS: Lublin.

Nowak, J. (2011). Aktywność obywateli online. Teorie a praktyka, Wydawnictwo UMCS: Lublin.

Nowina Konopka, M. (2006). Społeczeństwo informacyjne a teorie demokracji, in: Społeczeństwo informacyjne. Istota - rozwój- wyzwania, ed. M. Witkowska, K. Cholawo-Sosnowska, WAiP: Warsaw.

Ociepka, B. (1999). Wpływ nowych technologii na komunikowanie społeczne, in.: Studia z teorii komunikowania masowego, ed. B. Dobek-Ostrowska, Wydawnictwo Uniwersytetu Wrocławskiego: Wrocław.

Pisarek, W. (2007). O mediach i języku, WUJ: Kraków.

Poleszczuk, J. (2010). Kultura Internetu. Technologia komunikacji i problem integracji społecznej, in: Nie tylko Internet. Nowe media, przyroda, i „technologie społeczne” a praktyki kulturowe, ed. J. Mucha, WUJ: Kraków.

Popper, K. (1996). Prawo do telewizji, in: Condry, John, Popper, Karl, Telewizja zagrożenie dla demokracji, transl. M. Król, SIC: Warsaw.

Porębski, L. (2001). Elektroniczne oblicze polityki. Demokracja, państwo, instytucje polityczne w okresie rewolucji informacyjnej, Uczelniane Wydawnictwa NaukowoDydaktyczne AGH: Kraków. 
Schmitt, C. (2000). Definicja suwerenności; Problem suwerenności jako kwestia formy prawnej i decyzji, in: C. Schmitt, Teologia polityczna i inne pisma, transl. M. Cichocki, Znak: Kraków.

Skorowski, H. (1995). Z problematyki praw człowieka. Studium z katolickiej nauki społecznej, Wydawnictwo UKSW: Warsaw.

Sobczak, J. (2007). Media publiczne w procesie politycznym. Między niezależnością a uległością, in: M. Sokołowski, Media w Polsce. Pierwsza władza IV RP, WAiP: Warsaw.

Stalder, F. (2006). Manuel Castello. Teoria społeczeństwa sieci, transl. M. Król, WUJ: Kraków.

Szacka, B. (2003). Wprowadzenie do socjologii, Oficyna Naukowa: Warsaw.

Szlachta, B. (2003). O pojęciu „suwerenność” (kilka uwag historyka doktryn politycznych), Civita. Studia z filozofii polityki, No. 7, 2003.

Sztompka, P. (2002). Socjologia. Analiza społeczeństwa, Znak: Kraków.

Ward, S. (2010). Wasserman, Herman, Towards an Open Ethics: implications of new media platforms for global ethics discourse, in: Journal of Mass Media Ethics No. 4, 2010.

Zubik, M. (2011). Konstytucja III RP w tezach orzeczniczych Trybunału Konstytucyjnego i wybranych sądów, Wydawnictwo C. H. Beck: Warsaw.

Zwolinski, A. (2010). Dylematy demokracji, Wydawnictwo WAM: Kraków. 